\title{
Emergence of CD134 cysteine-rich domain 2 (CRD2)-independent strains of feline immunodeficiency virus (FIV) is associated with disease progression in naturally infected cats
}

\author{
Paweł M Bęczkowski ${ }^{1,2}$, Navapon Techakriengkrai ${ }^{1}$, Nicola Logan ${ }^{1}$, Elizabeth McMonagle ${ }^{1}$, Annette Litster ${ }^{3}$,
} Brian J Willett ${ }^{1}$ and Margaret J Hosie ${ }^{1 *}$

\begin{abstract}
Background: Feline immunodeficiency virus (FIV) infection is mediated by sequential interactions with CD134 and CXCR4. Field strains of virus vary in their dependence on cysteine-rich domain 2 (CRD2) of CD134 for infection.

Findings: Here, we analyse the receptor usage of viral variants in the blood of 39 naturally infected cats, revealing that CRD2-dependent viral variants dominate in early infection, evolving towards CRD2-independence with disease progression.
\end{abstract}

Conclusions: These findings are consistent with a shift in CRD2 of CD134 usage with disease progression.

Keywords: FIV, CD134, OX40, CRD2, Receptor, Evolution, Natural infection, Disease progression

\section{Findings}

The interaction between a virus and its cellular receptor is a primary event in viral replication and the specificity of the virus-receptor interaction influences both viral cell tropism and pathogenicity. While the primate lentiviruses target helper $\mathrm{T}$ cells by binding to $\mathrm{CD} 4$ [1-3], the feline immunodeficiency virus (FIV) attaches to helper $\mathrm{T}$ cells through an interaction with CD134 (OX40) $[4,5]$. Infection with either the primate or the feline lentiviruses requires a subsequent interaction with a member of the seven transmembrane domain (7TM) superfamily molecules; for the human immunodeficiency virus (HIV) the major co-receptors are CXCR4 and CCR5 [6-10], while FIV uses CXCR4 as a sole co-receptor [11,12].

Assessment of HIV-1 cell tropism may be used to monitor disease progression $[13,14]$ because progression is often associated with the emergence of either $\mathrm{X} 4$ viruses or dual-tropic viruses capable of using both CXCR4 and CCR5, ( X4R5 viruses) [15]. The emergence of X4 variants is usually accompanied by a rapid decline in the

\footnotetext{
* Correspondence: margaret.hosie@glasgow.ac.uk

'MRC-University of Glasgow Centre for Virus Research, Glasgow, UK Full list of author information is available at the end of the article
}

number of $\mathrm{CD} 4^{+} \mathrm{T}$ cells and the onset of immunodeficiency [16] and X4 or X4R5 viruses are present in $40-50 \%$ of HIV-1-infected individuals who progress to AIDS [17-20]. Like HIV, the cell tropism of FIV alters with disease progression; while $\mathrm{CD} 4^{+} \mathrm{T}$ cells are the predominant target in the acute (early) phase of infection, in the chronic (late) phase of infection, FIV also targets $\mathrm{CD}^{+} \mathrm{T}$ cells and $\mathrm{B}$ cells $[21,22]$. This shift in cell tropism between early and late viruses would seem counter-intuitive given that FIV infection is entirely dependent on sequential interactions between Env and CD134 [4,5,23] and CXCR4 [11,12,23-26]. Resolution of this enigma is offered by the observation that distinct strains of FIV differ in the nature of their interactions with CD134 [27-30]. It has been proposed that viruses requiring only CRD1 of CD134 for attachment (CRD2-independent strains) emerge during the later stages of disease $[30,31]$. In contrast, viruses that dominate in early infection require both CRD1 and CRD2 of CD134 for attachment (CRD2-dependent) [30,31]. The selective pressure for the emergence of CRD2-independent viruses may be escape from humoral or cellular immunity, with the accrued mutations in Env impacting on the virus-receptor interaction $[30,32]$. Consistent with this 
hypothesis, when cats were challenged with a reconstituted viral quasispecies containing equal titres of clonal variants with either CRD2-dependent or CRD2-independent Envs (early and late phenotypes), the CRD2-dependent viruses expanded preferentially in vivo while the CRD2-independent viruses failed to thrive [33].

\section{Methods}

In this study, we examined the phenotype of viral variants isolated from outbred, privately owned US cats with naturally acquired FIV infection [34]. Forty-four cats were enrolled in the study on the basis of a history of FIV infection (confirmed by virus isolation), regardless of breed, sex, age and health status. Four blood samples (denoted A, B, C and D) were collected from each cat at 6-monthly intervals over an 18-month period, unless cats died during the interim period. The data recorded every 6 months included signalment, clinical history, physical examination data and body weight, as well as flow cytometric analyses of $\mathrm{CD}^{+}$and $\mathrm{CD} 8^{+} \mathrm{T}$ cells [34].

Full-length FIV env genes were amplified from whole blood using a two-step nested PCR protocol followed by direct nucleic acid sequence determination [34]. The nucleic acid sequence of the first-round PCR product informed primer design for the second round PCR; strainspecific primers [see Additional file 1: Table S1] for second round PCR incorporated restriction sites to facilitate subcloning into the expression vector for pseudotyping onto HIV. HIV(FIV)luc pseudotypes were prepared as described previously [4] by co-transfection of each Env construct with
pNL4-3-Luc-E ${ }^{-}{ }^{-}$luc into HEK-293 T cells. Pseudotypecontaining culture fluids were harvested 72 hours posttransfection and stored frozen at $-80 \mathrm{C}$ until required.

The CRD2-dependence of each pseudotype was determined using assays for receptor usage of FIV Envs using MCC cells [35] expressing human (HHH), feline (FFF), and a feline $\mathrm{x}$ human chimaeric CD134 molecule containing human CRD2 (FFHH), as described previously [27,29].

Sequential plasma samples from infected cats were diluted ten-fold from 1 in 10 to 1 in 10,000 in complete RPMI 1640 medium (Life Technologies), before testing for the presence of homologous and heterologous neutralising antibodies (NAb) using HIV(FIV)luc pseudotypes as described previously [36].

\section{Results}

FIV Envs displayed a broad spectrum of cell tropism in naturally infected cats

While we cannot exclude the possibility that other variants existed in the cats, the methodology used provided a snapshot of the spectrum of Env variants present at each time point. The HIV(FIV) pseudotypes bearing FIV Envs derived from 39 (39/44, 88.6\%) of the infected cats displayed a broad spectrum of cell tropisms (viable pseudotypes bearing Envs from 5 cats were not produced, predominantly because premature stop codons occurred in the env sequences obtained from these cats). Of the 287 Envs tested, 222 (77.4\%) were CRD2-dependent, utilising CD134 in the same manner as the prototypic early isolate, GL-8 [Figure 1 and Table 1]. In contrast, 49 (17.0\%) Envs were CRD2-independent, similar to the

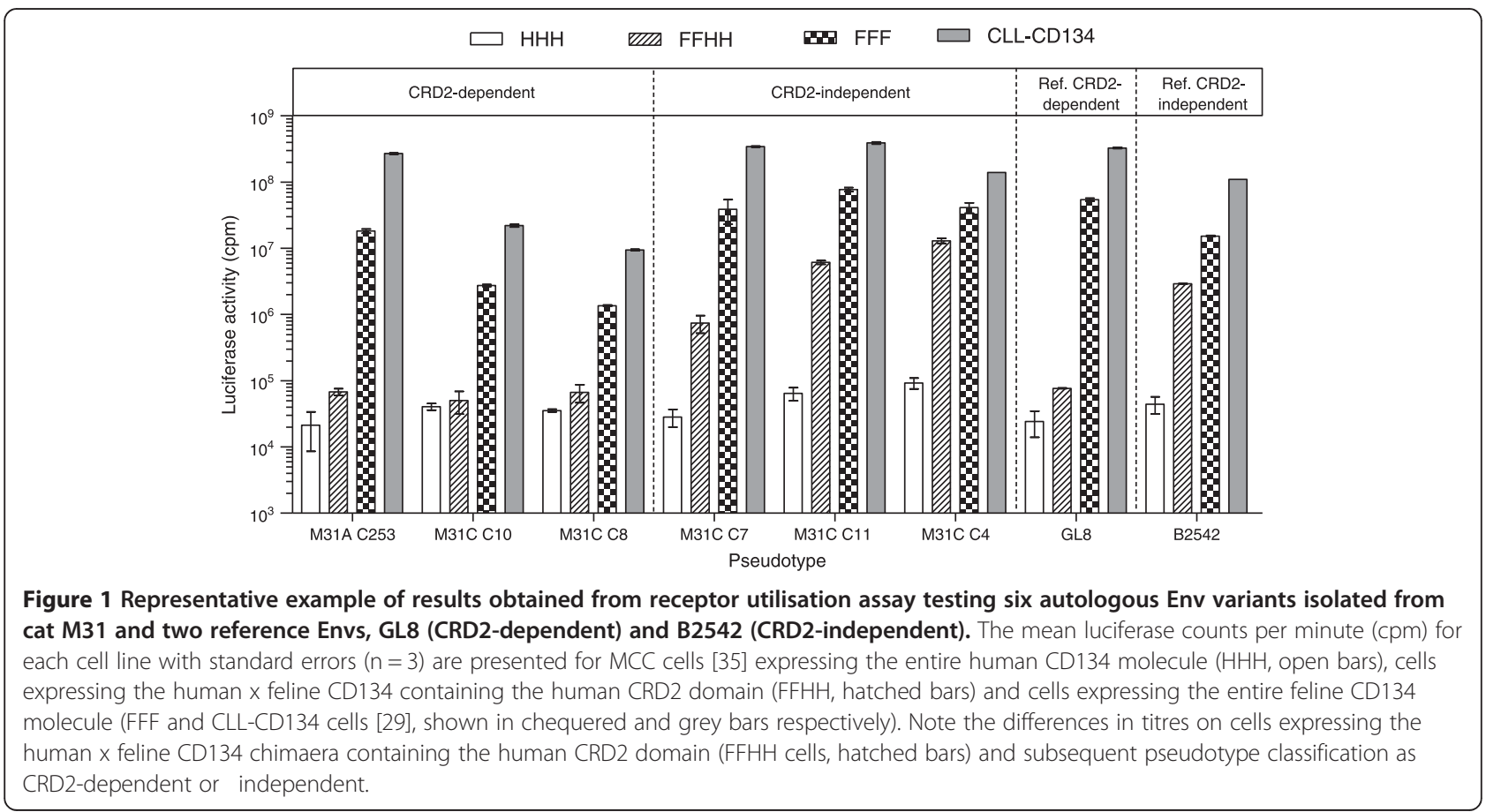


Table 1 Mode of CD134 utilisation displayed by 287 Envs from 39 cats

\begin{tabular}{|c|c|c|c|c|c|c|c|c|}
\hline \multirow{2}{*}{ Cat } & \multirow[t]{2}{*}{ Alive/Dead } & \multirow{2}{*}{$\begin{array}{l}\text { Health } \\
\text { status }\end{array}$} & \multirow{2}{*}{$\begin{array}{l}\text { CD4 } \\
\text { count }\end{array}$} & \multicolumn{3}{|c|}{ Mode of CD134 interaction } & \multirow{2}{*}{$\begin{array}{l}\text { No. of } \\
\text { Envs tested }\end{array}$} & \multirow{2}{*}{$\begin{array}{l}\text { Homologous } \\
\text { neutralisation }\end{array}$} \\
\hline & & & & CRD2-dependent & CRD2-independent & Intermediate & & \\
\hline $\mathrm{M} 28$ & A & $\mathrm{H}$ & $>350$ & $11(100 \%)$ & 0 & 0 & 11 & - \\
\hline M47 & A & $\mathrm{H}$ & $<350$ & $8(100 \%)$ & 0 & 0 & 8 & + \\
\hline M8 & A & $\mathrm{S}$ & $<350$ & $2(100 \%)$ & 0 & 0 & 2 & - \\
\hline P9 & A & $S$ & $<350$ & $6(100 \%)$ & 0 & 0 & 6 & + \\
\hline M1 & A & $\mathrm{H}$ & $<350$ & $4(100 \%)$ & 0 & 0 & 4 & - \\
\hline M2 & A & $\mathrm{H}$ & $>350$ & $2(100 \%)$ & 0 & 0 & 2 & + \\
\hline M29 & A & $\mathrm{H}$ & $>350$ & $3(100 \%)$ & 0 & 0 & 3 & - \\
\hline P1 & A & $\mathrm{H}$ & $>350$ & $3(100 \%)$ & 0 & 0 & 3 & - \\
\hline P11 & A & $\mathrm{H}$ & $>350$ & 7 (100\%) & 0 & 0 & 7 & + \\
\hline P14 & A & $\mathrm{H}$ & $>350$ & 9 (100\%) & 0 & 0 & 9 & + \\
\hline P18 & A & $\mathrm{H}$ & $>350$ & $1(100 \%)$ & 0 & 0 & 1 & + \\
\hline P21 & A & $\mathrm{H}$ & $>350$ & $6(100 \%)$ & 0 & 0 & 6 & - \\
\hline P22 & A & $\mathrm{H}$ & $>350$ & $2(100 \%)$ & 0 & 0 & 2 & + \\
\hline P4 & A & $\mathrm{H}$ & $<350$ & 4 (44.4\%) & $2(22.2 \%)$ & 3 (33.3\%) & 9 & + \\
\hline P5 & A & $\mathrm{H}$ & $<350$ & 7 (87.5\%) & 1 (12.5\%) & 0 & 8 & + \\
\hline P6 & A & $\mathrm{H}$ & $>350$ & $8(100 \%)$ & 0 & 0 & 8 & - \\
\hline M15 & A & $S$ & $>350$ & $6(66.6 \%)$ & 3 (33.3\%) & 0 & 9 & + \\
\hline M20 & A & S & $>350$ & $1(100 \%)$ & 0 & 0 & 1 & - \\
\hline M32 & A & $S$ & $<350$ & $3(75 \%)$ & $1(25 \%)$ & 0 & 4 & - \\
\hline P13 & A & S & $<350$ & 8 (88.9\%) & 1 (11.1\%) & 0 & 9 & + \\
\hline P17 & A & $\mathrm{S}$ & $<350$ & $9(100 \%)$ & 0 & 0 & 9 & - \\
\hline P7 & A & $S$ & $>350$ & $1(50 \%)$ & 0 & $1(50 \%)$ & 2 & + \\
\hline P8 & A & $S$ & $>350$ & $5(100 \%)$ & 0 & 0 & 5 & - \\
\hline M25 & $D$ & $\mathrm{H}$ & $<350$ & $3(50 \%)$ & 2 (33.3\%) & 1 (16.7\%) & 6 & + \\
\hline M46 & D & $\mathrm{H}$ & $<350$ & 7 (87.5\%) & $1(12.5 \%)$ & 0 & 8 & + \\
\hline M49 & $D$ & $\mathrm{H}$ & $<350$ & $6(100 \%)$ & 0 & 0 & 6 & + \\
\hline M14 & $D$ & S & $<350$ & $9(90 \%)$ & $1(10 \%)$ & 0 & 10 & + \\
\hline M26 & $D$ & $S$ & $<350$ & $4(66.7 \%)$ & 2 (33.3\%) & 0 & 6 & + \\
\hline M30 & $D$ & $\mathrm{~S}$ & $<350$ & 15 (94\%) & $1(6 \%)$ & 0 & 16 & + \\
\hline M33 & $\mathrm{D}$ & S & $<350$ & $2(11 \%)$ & 17 (89\%) & 0 & 19 & - \\
\hline M41 & $\mathrm{D}$ & S & $<350$ & $9(75 \%)$ & $2(17 \%)$ & $1(8 \%)$ & 12 & - \\
\hline M5 & $\mathrm{D}$ & $S$ & $<350$ & $5(55.6 \%)$ & $3(33.3 \%)$ & 1 (11.1\%) & 9 & - \\
\hline M11 & $D$ & $\mathrm{H}$ & $>350$ & 17 (81\%) & $3(14 \%)$ & $1(5 \%)$ & 21 & - \\
\hline M50 & $D$ & $\mathrm{H}$ & $>350$ & $2(100 \%)$ & 0 & 0 & 2 & - \\
\hline P2 & $\mathrm{D}$ & $\mathrm{H}$ & $>350$ & 16 (100\%) & 0 & 0 & 16 & + \\
\hline M16 & $D$ & S & $>350$ & 0 & 1 (14.3\%) & $6(85.7 \%)$ & 7 & - \\
\hline M3 & $D$ & $S$ & $<350$ & 0 & $1(50 \%)$ & $1(50 \%)$ & 2 & - \\
\hline M31 & D & S & $<350$ & $9(53 \%)$ & $7(41 \%)$ & $1(6 \%)$ & 17 & + \\
\hline M44 & D & S & $>350$ & $2(100 \%)$ & 0 & 0 & 2 & + \\
\hline
\end{tabular}

Cats were classified according to their clinical status at the time of enrolment ( $\mathrm{H}=$ clinically healthy, $\mathrm{S}=$ sick), $\mathrm{CD} 4^{+}$cell counts $(<$or $>350$ cells $/ \mathrm{\mu l})$ and survival during the study period $\left(A=\right.$ alive, $\mathrm{D}=$ deceased). For absolute $\mathrm{CD} 4^{+} \mathrm{T}$ cell counts see Additional file 2 [Table S2]. Mode of $\mathrm{CD} 134$ interaction: numbers (and percentages) of Envs classified as: 1) CRD2-dependent; 2) CRD2-independent; 3) intermediate requirement for determinants within CRD2. For homologous neutralisation, + and indicate $\geq$ or $<2.5$ fold neutralisation, respectively. For complete neutralisation data see Additional file 3 [Table S3]. 
representative late isolate, B2542. The remaining 16 Envs (5.6\%) displayed an intermediate pattern of receptor usage. Some cats (for example P4, M5 and M31) harboured a mixture of CRD2-dependent and -independent Env variants.

\section{CRD2-independence segregates with clinical status}

Since CRD2-independent variants of FIV were present in only a subset of the cats studied, we examined the data for evidence of an association between clinical status and the presence of CRD2-independent variants. Since the duration of infection was unknown, cats were grouped retrospectively according to their status at time of last sampling: Alive or Dead; Clinically Healthy (no clinical abnormalities detected on physical examination) or Sick (at least one clinical abnormality detected); a CD 4 count $>350$ cells $/ \mu$ l or $<350$ cells $/ \mu$ l. Statistical analysis of viral load data revealed no significant differences between cats that were classified as clinically healthy or sick at the time of enrolment (data not shown). When the number of cats giving rise to CRD2-independent Env variants was compared between groups, a strong association was noted between the presence of CRD2independent variants and a decline in clinical status [Figure 2]. Samples collected from cats that died during the study had a significantly higher proportion of CRD2independent variants than samples from cats that were alive at the time of last sampling $(p=0.0038$, Fisher $\mathrm{s}$ exact test). Similarly, sick cats (displaying clinical signs) harboured more CRD2-independent viruses than healthy cats ( $p=0.0104$, Fisher $\mathrm{s}$ exact test).

Given that a clinical assessment of health status may be subjective, we next used a CD4 count $<350$ cells/ $\mu \mathrm{l}$ as indicative of $\mathrm{CD}^{+}{ }^{+} \mathrm{T}$ cell depletion and progression to immunodeficiency (by analogy to WHO recommendations for the initiation of antiretroviral therapy for HIV infection [http://www.who.int/hiv/pub/guidelines/arv2013/en/]), for data see Additional file 2: Table S2. We observed that immunodeficient cats were more likely to harbour CRD2independent Envs than cats with CD4 counts $>350$ cells $/ \mu \mathrm{l}$ ( $\mathrm{p}=0.0036$, Fisher $\mathrm{s}$ exact test). Thus the presence of CRD2-independent viruses was associated with declining clinical status.

\section{Absence of correlation between CRD2-usage and neutralising antibody response}

When neutralisation profiles [see Additional file 3: Table S3] were compared [Table 1], plasma from 10/17 cats harbouring at least one CRD2-independent Env variant neutralised pseudotypes bearing homologous Envs, while the remaining 7 cats showed no evidence of homologous neutralisation ( $\mathrm{p}=0.75$, Fisher s exact test). Thus, no correlation was observed between the presence of neutralising antibodies and CRD2-independence, indicating that key factors driving Env evolution remain to be discovered.

\section{Loss of predicted $\mathrm{N}$-linked glycosylation site was associated with decrease in CRD2 dependence}

A complete spectrum of receptor utilisation was observed by pseudotypes bearing 21 Env variants isolated from three time points from cat M11 (until its death); 17/21 were CRD2-dependent, 3/21 were CRD2-independent, and one displayed an intermediate phenotype [Table 1]. Strikingly, the remaining pseudotype (M11A C242) infected cells expressing the CD134 chimaera containing the human CRD2 domain as efficiently as cells expressing the entire feline CD134 molecule [see Additional file 4: Figure S1]. Analysis of amino acid sequence alignments

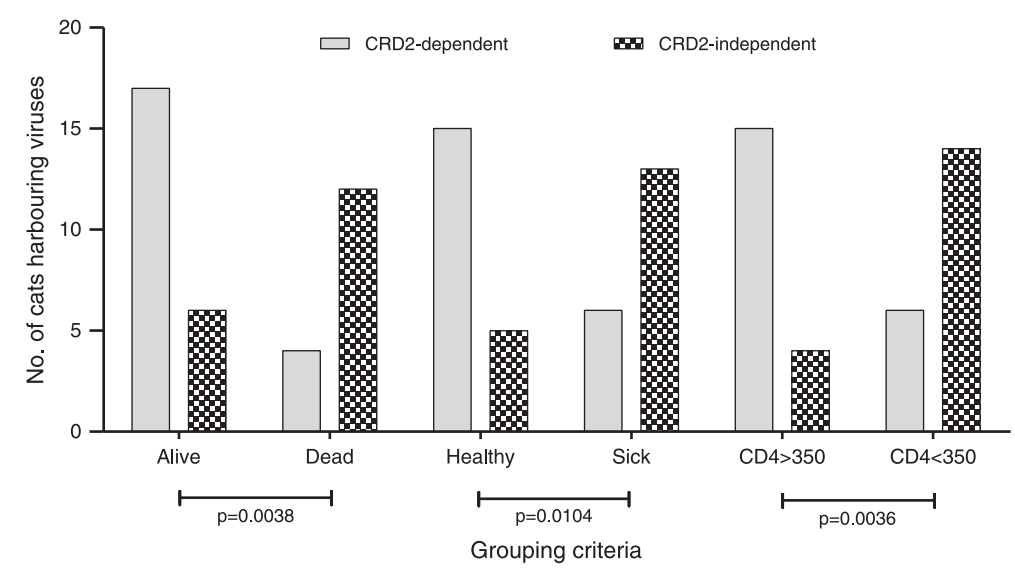

Figure 2 CRD2-independent Env variants were isolated more frequently from cats displaying signs of immunodeficiency and disease progression. Cats were classified into 3 groups: 1) alive/deceased, 2) clinically healthy/sick, 3) CD4 ${ }^{+} \mathrm{T}$ cell counts $>$ or $<350$ cells/ $\mu$ l. Cats which died during the study, displayed clinical signs (sick) or had CD4 ${ }^{+} \mathrm{T}$ cell counts $<350$ cells/ $\mu$ l were more likely to harbour at least one CRD2-independent

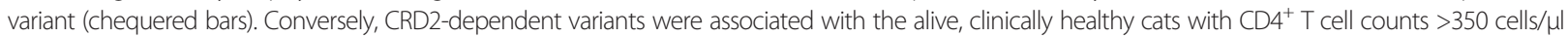
(grey bars). P-values (Fisher s exact test) were shown below the $\mathrm{x}$-axis. 
identified two unique mutations: 1) T520A and 2) E838K which were present in M11A C242 Env but not any other Env variants from this cat. The T520A substitution led to the loss of a predicted site for N-linked glycosylation (PNGS), consistent with a role for the T520A mutation in the observed decrease in CRD2 dependence. To confirm this observation, PCR-based site directed mutagenesis was employed to exchange 1) alanine at residue 520 to threonine (A520T) and 2) lysine at residue 838 to glutamate (K838E), creating two mutants, namely M11A C242 T520 and M11A C242 E838 respectively. By comparing the receptor utilisation of these mutant Envs with the wild type M11A C242 Env, we observed that the M11A C242 T520 mutant achieved a 10 fold lower titre on cells expressing the human $\mathrm{x}$ feline CD134 chimaera containing the human CRD2 domain compared to either the parental wild type M11A C242 or the M11A C242 E838 mutant Env, consistent with residue A520 in the wild type Env (ablating the PNGS) having an important role in receptor utilisation [see Additional file 4: Figure S1].

To confirm the role of A520 and the subsequent loss of a PNGS in determining receptor utilisation, mutants of the Env clone M11C C164, (CRD2-dependent phenotype) were constructed. Substitution of T520 with A520 resulted in the generation of mutant M11C C164 A520 that productively infected cells expressing the human $\mathrm{x}$ feline CD134 chimaera containing the human CRD2 domain [see Additional file 4: Figure S1], consistent with a role for the PNGS at residue 520 in modulating CRD2-dependence and altering the virus-receptor interaction.

The envelope glycoprotein adopts a trimeric structure upon the virion and it is likely that multiple determinants within Env may affect the tertiary or quaternary structure of the trimer, resulting in altered CD134 utilisation. The data presented here are consistent with previous studies $[29,32]$ indicating that single mutations within the V1/V2 or V5 regions of Env alone, likely as a result of pressure from the host immune response, may alter the structure of Env sufficiently to drive the emergence of CD134 CRD2-independent variants of FIV. Whether the emergence of such variants is a cause or consequence of disease progression remains to be established.

\section{Conclusion}

The studies described herein are consistent with the dominance of CRD2-dependent viruses in early infection and indicate that the emergence of CRD2-independent viruses coincides with clinical decline towards immunodeficiency. Accordingly, viral phenotyping using HIV(FIV) pseudotypes may assist with the clinical staging of FIV infection. Moreover, if CRD2-dependent viruses dominate in early infection, testing prototypic FIV vaccines against challenge with CRD2-dependent strains of virus will likely predict vaccine efficacy in the field.

\section{Additional files}

\begin{abstract}
Additional file 1: Table S1. Strain specific primer sequences.
Additional file 2: Table S2. $C D 4^{+} T$ cell counts (cells/ $\mu$ l) for each time
\end{abstract} point.

Additional file 3: Table S3. Mode of CD134 utilisation for each Env pseudotype.

Additional file 4: Figure S1. PNGS at the stem of V5 region of Env is associated with distinct mode of receptor utilisation.

\section{Competing interests}

The authors declare that they have no competing interests.

\section{Authors contributions}

$\mathrm{PB}, \mathrm{MH}, \mathrm{BW}$ and $\mathrm{AL}$ designed the study; $\mathrm{AL}$ recruited the cats, collected samples and provided statistical advice. PB and NL performed the DNA manipulations and prepared virus pseudotypes; $P B$ and EM performed the cell culture, neutralisation assays and biochemical analyses. PB, NT, BW and $\mathrm{MH}$ designed the experiments, interpreted the data and drafted the manuscript. All authors read and approved the final manuscript.

\section{Acknowledgements}

This study was supported by The Wellcome Trust. Blood sample collections were supported by the Purdue Maddie s Shelter Medicine Program, underwritten by a grant from Maddie s Fund, The Pet Rescue Foundation [www.maddiesfund.org], helping to fund the creation of a no-kill nation. We thank Kristen Hall CVT, Dr Jui Ming Lin, Dr Christian Leutenegger, PAWS

Chicago, Drennan Animal Hospital, the Fitzhugh B. Crews FIV Cat Sanctuary and participating cat owners for their assistance with the study and IDEXX Corporation (Westbrook, MN and West Sacramento, CA) for flow cytometric analyses.

\section{Author details}

${ }^{1}$ MRC-University of Glasgow Centre for Virus Research, Glasgow, UK. ${ }^{2}$ Small Animal Hospital, University of Glasgow, Glasgow, UK. ${ }^{3}$ Department of Veterinary Clinical Sciences, Purdue University, West Lafayette, IN 47907, USA.

Received: 21 July 2014 Accepted: 21 October 2014

Published online: 28 November 2014

\section{References}

1. Maddon PJ, Dalgleish AG, McDougal JS, Clapham PR, Weiss RA, Axel R: The T4 gene encodes the AIDS virus receptor and is expressed in the immune system and the brain. Cell 1986, 47:333 348.

2. Dalgleish AG, Beverley PCL, Clapham PR, Crawford DH, Greaves MF, Weiss RA: The CD4 (T4) antigen is an essential component of the receptor for the AIDS retrovirus. Nature 1984, 312:763 767.

3. Klatzmann D, Champagne E, Chamaret S, Guetard D, Hercend T, Gluckmann JC, Montagnier L: T-lymphocyte T4 molecule behaves as the receptor for human retrovirus LAV. Nature 1984, 312:767 768.

4. Shimojima M, Miyazawa T, Ikeda Y, McMonagle EL, Haining H, Akashi $H$, Takeuchi Y, Hosie MJ, Willett BJ: Use of CD134 as a primary receptor by the feline immunodeficiency virus. Science 2004, 303:1192 1195.

5. de Parseval A, Chatterji U, Sun P, Elder JH: Feline immunodeficiency virus targets activated CD4+ T cells by using CD134 as a binding receptor. Proc Natl Acad Sci U S A 2004, 101:13044 13049.

6. Bleul CC, Wu LJ, Hoxie JA, Springer TA, Mackay CR: The HIV coreceptors CXCR4 and CCR5 are differentially expressed and regulated on human T lymphocytes. Proc Natl Acad Sci U S A 1997, 94:1925 1930.

7. Feng Y, Broder CC, Kennedy PE, Berger EA: HIV-1 entry co-factor: functional CDNA cloning of a seven-transmembrane, $G$ protein-coupled receptor. Science 1996, 272:872 877 .

8. Alkhatib G, Combadiere C, Broder CC, Feng Y, Kennedy PE, Murphy PM, Berger EA: CC CKR5: A RANTES, MIP-1alpha, MIP-1beta receptor as a fusion cofactor for macrophage-tropic HIV-1. Science 1996, 272:1955 1958.

9. Trkola A, Dragic T, Arthos J, Binley JM, Olson WC, Allaway GP, Cheng-Mayer C, Robinson J, Maddon PJ, Moore JP: CD4-dependent, antibody-sensitive interactions between HIV-1 and its co-receptor CCR-5. Nature 1996, 384:184 187. 
10. Berson JF, Long D, Doranz BJ, Rucker J, Jirik FR, Doms RW: A seven transmembrane domain receptor involved in fusion and entry of T-cell-tropic human immunodeficiency virus type 1 strains. J Virol 1996, 70:6288 6295

11. Willett BJ, Hosie MJ, Neil JC, Turner JD, Hoxie JA: Common mechanism of infection by lentiviruses. Nature 1997, 385:587.

12. Willett BJ, Picard L, Hosie MJ, Turner JD, Adema K, Clapham PR: Shared usage of the chemokine receptor CXCR4 by the feline and human immunodeficiency viruses. J Virol 1997, 71:6407 6415.

13. Waters L, Mandalia S, Randell P, Wildfire A, Gazzard B, Moyle G: The impact of HIV tropism on decreases in CD4 cell count, clinical progression, and subsequent response to a first antiretroviral therapy regimen. Clin Infect Dis 2008, 46:1617 1623.

14. Shepherd JC, Jacobson LP, Qiao W, Jamieson BD, Phair JP, Piazza P, Quinn TC, Margolick JB: Emergence and persistence of CXCR4-tropic HIV-1 in a population of men from the multicenter AIDS cohort study. J Infect Dis 2008, 198:1104 1112

15. Connor RI, Sheridan KE, Ceradini D, Choe S, Landau NR: Change in coreceptor use correlates with disease progression in HIV-1-infected individuals. J Exp Med 1997, 185:621 628.

16. Jekle A, Keppler OT, De Clercq E, Schols D, Weinstein M, Goldsmith MA: In vivo evolution of human immunodeficiency virus type 1 toward increased pathogenicity through CXCR4-mediated killing of uninfected CD4 T cells. J Virol 2003, 77:5846 5854.

17. Jansson M, Backstrom E, Bjorndal A, Holmberg V, Rossi P, Fenyo EM, Popovic M, Albert J, Wigzell H: Coreceptor usage and RANTES sensitivity of non-syncytium-inducing HIV-1 isolates obtained from patients with AIDS. J Hum Virol 1999, 2:325 338.

18. Li S, Juarez J, Alali M, Dwyer D, Collman R, Cunningham A, Naif HM: Persistent CCR5 utilization and enhanced macrophage tropism by primary blood human immunodeficiency virus type 1 isolates from advanced stages of disease and comparison to tissue-derived isolates. J Virol 1999, 73:9741 9755.

19. Karlsson I, Antonsson L, Shi Y, Oberg M, Karlsson A, Albert J, Olde B, Owman C, Jansson M, Fenyo EM: Coevolution of RANTES sensitivity and mode of CCR5 receptor use by human immunodeficiency virus type 1 of the R5 phenotype. J Virol 2004, 78:11807 11815.

20. Regoes RR, Bonhoeffer S: The HIV coreceptor switch: a population dynamical perspective. Trends Microbiol 2005, 13:269 277.

21. English RV, Johnson CM, Gebhard DH, Tompkins MB: In vivo lymphocyte tropism of feline immunodeficiency virus. J Virol 1993, 67:5175 5186

22. Dean GA, Reubel GH, Moore PF, Pedersen NC: Proviral burden and infection kinetics of feline immunodeficiency virus in lymphocyte subsets of blood and lymph node. J Virol 1996, 70:5165 5169.

23. de Parseval A, Grant CK, Sastry KJ, Elder JH: Sequential CD134-CXCR4 interactions in feline immunodeficiency virus (FIV): soluble CD134 activates FIV Env for CXCR4-dependent entry and reveals a cryptic neutralization epitope. J Virol 2006, 80:3088 3091

24. Hu QY, Fink E, Hong Y, Wang C, Grant CK, Elder JH: Fine definition of the CXCR4-binding region on the V3 loop of feline immunodeficiency virus surface glycoprotein. PLOS One 2010, 5:e10689.

25. Sundstrom M, White RL, de Parseval A, Sastry KJ, Morris G, Grant CK, Elder JH: Mapping of the CXCR4 binding site within variable region 3 of the feline immunodeficiency virus surface glycoprotein. J Virol 2008, 82:91349142.

26. Poeschla EM, Looney DJ: CXCR4 requirement for a nonprimate lentivirus: heterologous expression of FIV in human, rodent and feline cells. J Virol 1998, 72:6858 6866 .

27. Willett BJ, McMonagle EL, Bonci F, Pistello M, Hosie MJ: Mapping the domains of CD134 as a functional receptor for feline immunodeficiency virus. J Virol 2006, 80:7744 7747.

28. Willett BJ, McMonagle EL, Logan N, Spiller OB, Schneider P, Hosie MJ: Probing the interaction between the feline immunodeficiency virus and CD134 using a novel monoclonal antibody 7D6 and CD134L (OX40L). J Virol 2007, 81:9665 9679.

29. Willett BJ, McMonagle EL, Ridha S, Hosie MJ: Differential utilization of CD134 as a functional receptor by diverse strains of feline immunodeficiency virus (FIV). J Virol 2006, 80:3386 3394.

30. Willett BJ, Hosie MJ: The virus-receptor interaction in the replication of feline immunodeficiency virus (FIV). Curr Opin Virol 2013, 3:670 675.
31. Willett BJ, Hosie MJ: Chemokine receptors and co-stimulatory molecules: Unravelling feline immunodeficiency virus infection. Vet Immunol Immunopathol 2008, 123:56 64

32. Willett BJ, McMonagle EL, Logan N, Samman A, Hosie MJ: A single site for $\mathrm{N}$-linked glycosylation in the envelope glycoprotein of feline immunodeficiency virus modulates the virus-receptor interaction. Retrovirology 2008, 5:77.

33. Willett BJ, Kraase M, Logan N, McMonagle E, Varela M, Hosie MJ: Selective expansion of viral variants following experimental transmission of a reconstituted feline immunodeficiency virus quasispecies. PLoS One 2013, 8:e54871.

34. Bęczkowski PM: Virus evolution in the progression of natural feline immunodeficiency virus infection. PhD Thesis. University of Glasgow, Centre for Virus Research; 2013

35. Cheney CM, Rojko JL, Kociba GJ, Wellman ML, Dibartola SP, Rezanka LJ, Forman L, Mathes LE: A feline large granular lymphoma and its derived cell-line. In Vitro Cell Dev Biol 1990, 26:455 463.

36. Samman A, Logan N, McMonagle EL, Ishida T, Mochizuki M, Willett BJ, Hosie MJ: Neutralization of feline immunodeficiency virus by antibodies targeting the V5 loop of Env. J Gen Virol 2010, 91:242 249.

\section{doi:10.1186/s12977-014-0095-7}

Cite this article as: Bęczkowski et al:: Emergence of CD134 cysteine-rich domain 2 (CRD2)-independent strains of feline immunodeficiency virus (FIV) is associated with disease progression in naturally infected cats. Retrovirology 2014 11:95.

\section{Submit your next manuscript to BioMed Central and take full advantage of:}

$\bigotimes$ Convenient online submission

$\otimes$ Thorough peer review

$\otimes$ No space constraints or color $\nabla$ gure charges

$\otimes$ Immediate publication on acceptance

Q Inclusion in PubMed, CAS, Scopus and Google Scholar

$\nabla$ Research which is freely available for redistribution

Submit your manuscript at www.biomedcentral.com/submit
C BioMed Central 